\title{
USING GIS \& MULTICRITERIA DECISION ANALYSIS IN LANDSLIDE SUSCEPTIBILITY MAPPING - A CASE STUDY IN MESSINIA PREFECTURE AREA (SW PELOPONNESUS, GREECE)
}

\author{
Ladas I. ${ }^{1}$, Fountoulis $\mathbf{I}^{1}{ }^{1}$, and Mariolakos $\mathbf{I}^{1}{ }^{1}$ \\ ${ }^{1}$ National and Kapodistrian University of Athens, Faculty of Geology and Geoenvironment, \\ Department of Dynamic, Tectonic and Applied Geology, iladas@geol.uoa.gr, \\ fountoulis@geol.uoa.gr,mariolakos@geol.uoa.gr
}

\begin{abstract}
The purpose of this study is to assess the susceptibility of landslides at the eastern part of Messinia prefecture using GIS and Multicriteria Decision Analysis. Analytic Hierarchy Process and Weighted Linear Combination method were used to create a landslide susceptibility map for the study area. The produced map provides valuable information concerning the stability conditions of the territory and may serve as the first step in a complete hazard assessment towards the mitigation of natural landslide disasters in Messinia Prefecture area. Particularly the intention is to transfer effectively information regarding slope stability to non-geologists who take decisions for future land use planning processes and major construction projects.
\end{abstract}

Key words: Analytic Hierarchy Process, Weighted Linear Combination, Kalamata.

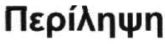

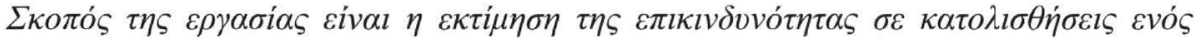

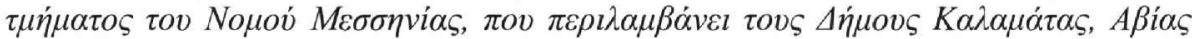

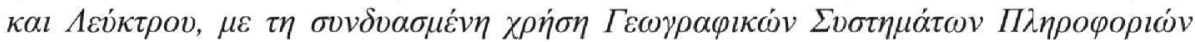

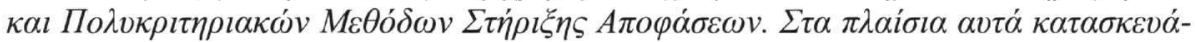

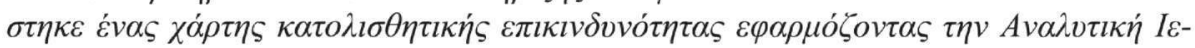

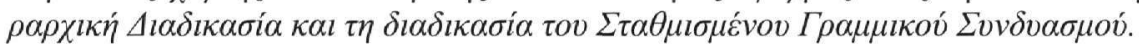

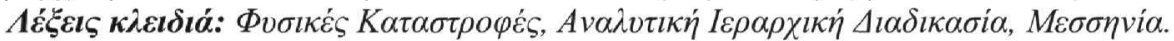

\section{Introduction}

Concerning the various natural hazards occurring in Messinia Prefecture area, (SW Peloponnesus, Greece), landslides are among the most common and hazardous ones. Tsakona landslide, (February 2003), at the boundary between Arcadia and Messinia, is a burning example that have caused the total destruction of a part of the new highway which connects the two prefectures (Fountoulis et al. 2004). The total volume of the removed material of this landslide was estimated as about $9 \times 10^{6} \mathrm{~m}^{3}$ and the economic losses are expected to reach millions of euros.

The study area covers a region of about 669 square kilometers in SE Messinia Prefecture. The broader area is considered as one of the most active ones in Greece as it is located very close to the 
Hellenic trench, which represents a major subduction zone. From a geomorphological point of view the territory of the study area can be generally distinguished into three regions: (i) The plain region of lower Messinia basin (west of Kalamata), (ii) The mountainous region of Mt. Taygetos which its peak has an altitude of $2.404 \mathrm{~m}$, (iii) The hilly regions developed mostly in the postalpine formations at the transitional zone between Taygetos Mt. and Messiniakos gulf.

The main drainage networks are the rivers Nedon, Xerilas, Koskaraka and Viros. The general stream direction is from NE to SW except Koskaraka, which forms a gorge flowing initially from north to south and then from east to west (Fig. 1). All the preceding streams are flowing only during rainy periods and discharge in Messiniakos gulf. The largest settlements are arranged along the coastline (Kalamata, Kardamyli, Stoupa) but there are many small villages scattered throughout the majority of the territory.

Landslide susceptibility zonation mapping was defined by Guzzetti et al. (1999) as the quantitative prediction of the spatial distribution of both landslide deposits and slopes. In this study, GIS software, ArcMap 9.0, was used as the basic analysis tool for spatial management and data manipulation. As the creation of thematic maps involves the interpolation of a large amount of data the use of GIS has proved its necessity. Likewise, as spatial decision problems involve a large set of conflicting evaluation criteria a multiple criteria approach is needed to be integrated with the GIS.

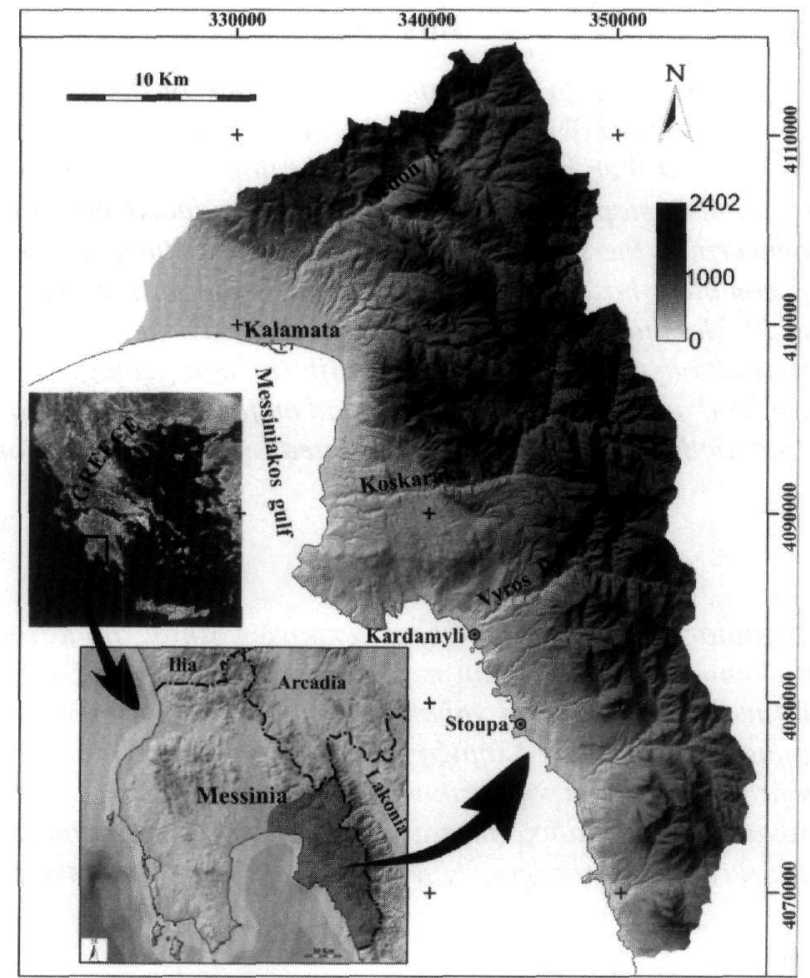

Figure 1 - Location map and shaded image of the DEM of the study area

\section{Geological and structural setting}

At the Messinia area, the following four alpine geotectonic units, from lower to upper, are present: (i) the Mani unit (mainly marbles, L. Senonian - L. Eocene), (ii) the Arna unit (mainly phyllites and quartzites), (iii) the Tripolis unit (shallow-water cabonates, Triassic - L. Eocene and flysch, L. Eocene-E. Miocene), and (iv) the Pindos unit (pelagic limestones, radiolarites, the so-called "first flysch", thin-bedded limestones, L. Cretaceous and flysch, Danian - Eocene). From the structural point of view, the 4-abovementioned geotectonic units form a succession of three nappes. Mani 
unit (slightly metamorphosed) is considered to be the relatively autochthonous one. Arna unit overthrusts Mani unit, Tripolis init (the second nappe) overthrusts Arna unit and Pindos unit the third nappe) overthrusts Tripolis unit.

The post alpine deposits outcropping in the study area can be distinguished into (i) marine, (ii) terrestrial and (iii) lacustrine formations (Mariolakos et al. 1995). The marine deposits consist of marls, sandstones and conglomerates. They occur in all the neotectonic basins of the study area and are of Upper Pliocene to Lower Pleistocene in age. The terrestrial deposits mainly represent red-colored siliceous sands and conglomerates alternating with clay.

The neotectonic macrostructure of SW Peloponnesus is characterized by the presence of large grabens and horsts bounded by wide fault zones, striking N-S and E-W. The main $1^{\text {st }}$ order macrostructures in the broader area are (Fig. 2a): (a) the Taygetos horst and (b) the Kalamata-Kyparissia mega-graben. The kinematic evolution of these neotectonic units is complicated since block rotation differentiates the uplift and subsidence rates throughout the margins of the neotectonic blocks, (Mariolakos et al. 1995).

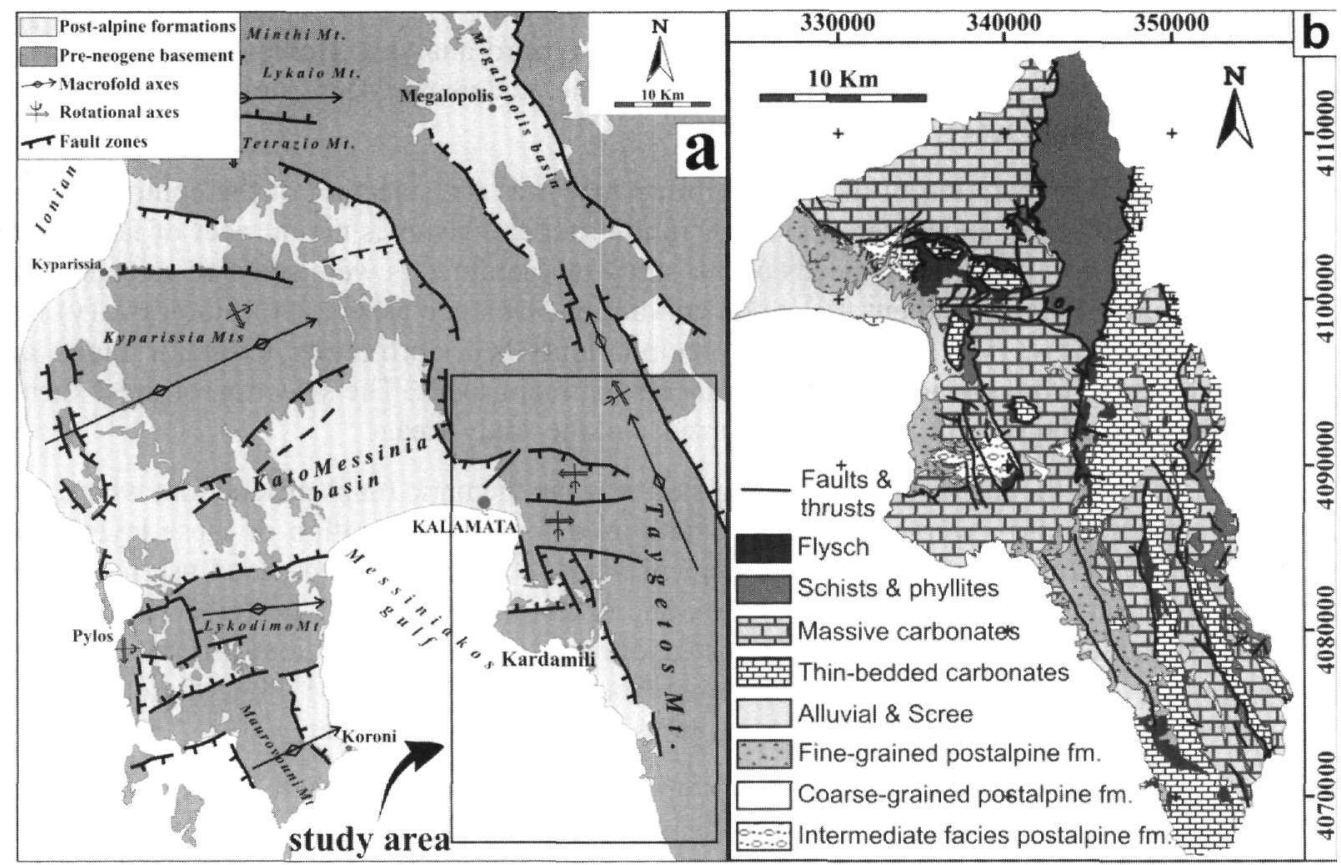

Figure 2 - (a) Sketch map of the main neotectonic macrostructures of the broader area, (b) Reclassified geological map based on the geotechnical behavior of the main lithologies occurring in the area

At the margins or within these $1^{\text {st }}$ order neotectonic macrostructures a great number of smaller structures are present. These neotectonic structures of minor order are dynamically related, as they have resulted from the same stress field but they have a different kinematic evolution. This differentiation has initiated either during the first stages of their creation, or later, during their evolution (Mariolakos et al. 1995).

\section{Methodology}

In our study we implemented Multicriteria Decision Analysis (MCDA) and GIS for the preparation of a landslide susceptibility map at the eastern part of Messinia prefecture that includes the municipalities of Kalamata, Avia and Leuktro. The primary issue in MCDA is concerned with how to combine the information from several criteria (factors) to form a single index of evaluation. 
There is no agreement on the methods for susceptibility maps production as several qualitative and quantitative methods were proposed for landslide susceptibility evaluation. Reviews on these techniques and methodologies, developed in the past decades, are given by various researchers (Aleotti and Chowdhury 1999, Guzzeti et al. 1999, Huabin et al. 2005).

In our study, the weighted linear combination method (WLC) was applied for the creation of the susceptibility map. This method consists of the construction of several thematic maps each one representing a landslide factor and for each factor we must identify a number of classes. As a result the territory in each thematic map is divided into homogenous areas according to the factor's classes. In WLC method the classes of the factors are standardized to a common numeric range and then combined by means of a weighted average.

The factors that are responsible for landslide occurrences could be distinguished into controlling (or causal) factors and triggering factors. The causal factors determine the initial favorable conditions for landslide occurrence while the triggering factors determine the timing of landsliding. Intensive rainfalls, earthquakes and human activities are the most common triggering mechanisms for slope failures in the study area. These triggering mechanisms are unpredictable, as they vary in time, and therefore it is very difficult to use them in a hazard analysis. However, the controlling factors can be represented by relevant thematic maps generated using GIS techniques and therefore can be used by landslide susceptibility mapping.

The first task in the preparation of the susceptibility map was the selection of the controlling factors. A common difficulty encountered in every multicriteria analysis is the number of factors that must be taken into account. For the needs of our study ten parameters were selected as controlling factors. These are (i) slope gradient, (ii) slope curvature, (iii) slope aspect, (iv) lithology, (v) land use, (vi) soil thickness, (vii) mean annual precipitations, (viii) proximity to major faults and thrusts, (ix) distance from streams and (x) distance from main roads. The selection of these factors was based on their affinity with landslide occurrence in the study area.

After the selection of the factors, the following step was the thematic maps production, where each factor was classified into several classes. The data used for the preparation of these layers were obtained from topographical base maps, geological maps, neotectonic maps, land use maps, land resource maps, rainfall data, personal fieldwork and ortho-photography as described in details in the following chapters. The thematic maps corresponding to (a) slope gradient, (b) curvature and (c) aspect, were obtained directly in raster format from the produced DEM while the others were produced by vector format digitization that was transformed in raster format.

The next step was to assign weights and rank values to the raster layers (representing factors) and to the classes of each layer respectively. This step was realized with the use of the Analytic Hierarchy Process, developed by Saaty (1980), in order to achieve objectivity on the weight assignment. Finally the weighted raster thematic maps with the assigned ranking values for their classes were multiplied by the corresponding weights and added up to yield a simple map where each cell has a certain landslide susceptibility index (LSI) value. This map after reclassification represents the final susceptibility map of the study area.

\section{DEM application}

The quality of the produced susceptibility maps depends on the data layers used. The digital elevation model (DEM) represents the basic data layer from which various topographic parameters can be digitally generated. For the study area was created a contour-based DEM with a ground resolution of $15 \times 15 \mathrm{~m}$. This cell size was selected according to the quality and the accuracy of the output data after the experimental creation of various DEMs with different resolutions. The original DEM was derived by TIN interpolation from $20 \mathrm{~m}$ elevation digitized contours obtained from the existing topographic sheets of the Hellenic Military Geographical Service of 1:50.000 scale. Contour interpolation was based on the Greek Geodetic Reference System (GGRS'87) projection. Moreover, 
other input elevation data were derived from the same maps such as trigonometric points and spot heights. The produced DEM was evaluated satisfactory, by creating contour lines from the new surface and comparing them with the original input contours.

\section{Conditioning factors}

\subsection{Slope gradient}

Slope gradient is an important parameter as it controls the subsurface flow velocity after rainfalls, the runoff rate and the soil water content. As slope increases shear stress in unconsolidated soil cover generally increases as well. The original raster format file was obtained directly from the DEM using Horn's method. It was processed in degrees with slope values ranging from $0^{\circ}$ to $89^{\circ}$. In the reclassified map, used in the multi-criteria analysis, slope values were subdivided into the following five classes: (a) Very gentle slopes, $<5^{\circ}$, (b) Gentle slopes, $5^{\circ}-15^{\circ}$, (c) Moderately steep slopes, $15^{\circ}-30^{\circ}$, (d) Steep slopes, $30^{\circ}-45^{\circ}$ and (e) Escarpments, $>45^{\circ}$.

Generally, landslides are not expected to occur on gentle slopes due to lower sheer stress. In the study area we define that very steep natural slopes and escarpments (over $45^{\circ}$ ) have also low susceptibility to landslides. This is due to the fact that slopes made of semi-consolidated and weathered rocks cannot be so steep. Such slopes are mainly developed in areas comprising of resistant massive carbonate rocks which are mainly subjected to rockfall hazard. Excepting the escarpments, for the other classes it is expected that landslide susceptibility increase along with the increase in slope steepness reaching the maximum in the $4^{\text {th }}$ class $\left(30^{0}-45^{0}\right)$.

\subsection{Curvature}

Curvature values represent the morphology of topography. It can be calculated in terms of plan curvature (which is perpendicular to the direction of the maximum slope), profile curvature (which is in the direction of the maximum slope) and general curvature. In our study we have taken into consideration the general curvature since it combines the characteristics of the two first ones. Curvature was selected as a causal factor on the basis that it affects the hydrological conditions of the soil cover. Potentially, after rainfalls the soil cover on a concave slope can contain more water and retain it for a longer period than a convex slope. On the other hand at many places convex slopes mark the outcrop of strong bedrock among looser rocks. Consequently, the concave slope profile areas have higher probability for a landslide occurrence than the convex areas. In the curvature raster file the positive curvature values indicate that the surface is convex at those cells. On the contrary the negative values indicate that the surface is concave at those cells. A value of zero indicates that the surface is flat. The more negative the value the higher the probability of landslide occurrence and the more positive the value the lower the probability.

\subsection{Slope aspect}

Considering the influence of aspect it can be supposed that it has an affect on the exposure to sunlight and to drying winds, affecting indirectly other factors such as the flora distribution, the degree of saturation and evapotranspiration of the slopes and the soil thickness. In the northern hemisphere, at middle and high latitudes, it is generally considered that the N and NW-facing slopes are the most favorable to landsliding due to their shadier and colder conditions that favor the accumulation and preservation of soil moisture (Guzetti et al. 1999). Thus the frequency of landslides is expected to be higher on north and NW-facing slopes, due to larger water accumulation and lower on east-facing and SE-facing slopes as a result of decreased wetness. The aspect raster map has been divided into nine classes, representing angular sectors of $45^{\circ}$ wide, namely, $\mathrm{N}$, NE, E, SE, S, SW, W, NW, N and flats. 


\subsection{Lithology}

It is well known that lithology is a major controlling factor for landslides. In this study the basic data used to generate the original geological map in vector format where obtained: (i) from the existing geological maps published by the Institute of Geology and Mineral Exploration (scale 1:50.000), revised at various sites after fieldwork, (ii) the geological maps produced from the Microzonation study of Kalamata project (Mariolakos et al. 1986), scale 1:5.000 and (iii) the major fault zones derived from Mariolakos et al. (1993), and unpublished neotectonic maps (Kalamata Kardamyli scale 1:50.000).

In the produced geological map, after the combination of the abovementioned maps, the alpine and post-alpine formations were grouped into lithological units based on the relative strength and stability of each formation. As a result the final reclassified map (Fig. 2b) was reduced to the following 8 categories which have different susceptibilities to landsliding and accordingly are assigned a higher or lower ranking value: (i) massive carbonates, (ii) thin bedded carbonate rocks, (iii) schists \& phyllites, (iv) flysch formations, (v) alluvial and scree, (vi) fine-grained post-alpine formations, (vii) intermediate facies post-alpine formations, (viii) coarse-grained post-alpine formations.

\subsection{Land use}

Land use is considered to be an important landslide-controlling factor since it affects the hydrological conditions and the soil strength. In our study the land use classes were derived from existing maps (CORINE 2000 program) and grouped into relevant units. The initial input data were fairly changed for various areas after comparing them with a set of 1:5.000-scale color orthophotos. Eight land use classes have been identified by reclassification of the original land use categories namely, (a) Arable land, (b) build-up areas, (c) dense forests, (d) Transitional forest-shrubs areas, (e) rocky areas, (f) agriculture, (g) mixed cultivated-shrub areas, (h) shrubs \& grassland.

The aforementioned land cover classes have different landslide susceptibility. The density of vegetation has a strong influence on the stability of superficial deposits both hydrological (capacity of infiltration into the soil, soil moisture, groundwater level, etc.) and mechanical as the roots increase the shear strength of the soil. Sparsely vegetated areas are in general more vulnerable to erosion and exhibit greater instability as compared to densely vegetated areas. Agricultural land is considered to represent relative stable areas as agriculture is generally practiced on low slopes and due to human activity slope failures in farms and groves are kept under control. Lower ranking values were also assigned to built-up and rocky areas.

\subsection{Soil thickness}

The variable thickness of soil indicates the capability of generating pore water pressures and the presence of susceptible material. Increase of the thickness results in more favorable landslide conditions since the contact between the bedrock and the soil cover may act as a sliding surface. In our study the inferred depth of the soil cover has been used for awarding the ratings. The original data were obtained from the 1:50.000 scale land resource maps of the Ministry of Agriculture. In the created thematic map the territory was subdivided into 5 classes namely, (a) deep soil, (b) mixed shallow \& deep soil areas, (c) mixed bare rock \& deep soil areas, (d) shallow soil, (e) bare rock.

\subsection{Mean annual rainfall}

Due to the lacking of detailed data such as maximum daily rainfall only the annual precipitations were taken into consideration. Monthly rainfall data were collected from five stations in the study area. Average annual total precipitations at the Kalamata meteorological station near sea level is $786 \mathrm{~mm}$. This value changes scientifically along the elevation gradient reaching $1063 \mathrm{~mm}$ at Artemisia station ( $760 \mathrm{~m}$ altitude) and $1416 \mathrm{~mm}$ at Soha station ( $875 \mathrm{~m}$ altitude) in the Taygetos mountainous area. Taking this factor into account the territory in the created thematic map was divided into 3 classes with different mean annual rainfall rates namely, (a) $<1000 \mathrm{~mm}$, (b) 1000 - 
$1500 \mathrm{~mm}$, (c) $>1500 \mathrm{~mm}$. Potentially, the higher the rate the more favorable the conditions for landsliding.

\subsection{Distance from roads}

Another evaluation factor related to the occurrence of landslides is the distance from road network. It is considered that landslide susceptibility decreases with increasing distance from the main roads located on hilly and mountainous areas. This consideration is based on the general hypothesis that landslides are more frequent in areas closer to roads, due to inappropriate road sections and drainage from the road. For deriving the road network vector map we digitized the main roads from the 1:50.000-scale topographic sheets of the Hellenic Military Geographical Service. The thematic map was made, by applying a buffer to the main roads. Therefore, the study area was divided into two different buffer ranges: (a) areas within 50 meters from roads, (b) all the rest of the areas.

\subsection{Distance from streams}

The original drainage network map was produced by the digitization of the 1:50.000-scale topographic sheets. The thematic map was generated using a buffer around the streams of the drainage network. It was classified in two distance classes $(<50$ meter from streams, all the rest of the areas). This factor was taken into account on the hypothesis that streams affect the stability of the slopes both by saturating and undercutting them. Consequently, as the distance from the streams increases the hazard of landslide decreases. Hence, the classes of the buffered map have been given rating values in decreasing order based on the distance from the streams.

\subsection{Proximity to thrusts and fault zones}

It is observed that landslides are more abundant along thrust planes and major faults. Proximity of landslide occurrence to thrusts is a consequence of the contacts between overlying more permeable rocks and underlying less permeable or impermeable formations resulting in abundance of springs. On the other hand fault zones increase landslide potential by creating steep slopes and sheared zones of weakened and fractured rocks. The major faults and thrusts included in the study area have been digitized from the geological and neotectonic maps and superimposed to form a vector layer. On this layer we applied a distance function to define buffer zones along the structural discontinuities. We created two buffer zones each one of $150 \mathrm{~m}$ wide. The territory included in these zones represents areas of different influence of the tectonic features on landslides occurrence. As the distance from the tectonic lineaments increases landslide frequency decreases, thus the buffered regions were rated according to their distance from the faults and thrusts.

\section{Factor Analysis}

All the primary vector thematic map-layers presented in the aforementioned paragraphs were converted into raster format for future analysis through a vector to raster conversion procedure using a pixel size of $15 \times 15 \mathrm{~m}$. This cell size was selected in order to match the spatial resolution of the DEM and to confirm to the detail and resolution of the original maps (scale 1:50.000).

Slope failures represent the interplay result of various factors but the influence of each factor on the occurrence of landslides is not equal and therefore it must be weighted. Various methods have been proposed in literature for the preparation of landslide susceptibility maps and factor weighting (Huabin et al. 2005). For this study, the Analytic Hierarchy Process (AHP), developed by Saaty (1980), was selected as the decision analysis tool for the evaluation of the relative weight of each factor. AHP is a popular semi-qualitative method accessed in order to introduce objectivity in weight assignment (Barredo et al. 2000, Ayalew et al. 2005, Akgun et al. 2006). In AHP all factors are compared pairwise in terms of the intensity of their importance using a continuous 1 to 9 point scale shown in Table 1. This scale, used for the comparisons, enables the decision-maker to incorporate experience and knowledge intuitively. It is also insensitive to small changes in decision maker's preferences, thereby minimizing the effect of uncertainty in evaluations. 
Using Expert Choice 11 software (trial version) we build the pairwise comparison matrix needed to calculate factor weights in AHP as shown in table 2. The diagonal boxes of the matrix take a value of 1 while the boxes in the upper and lower halves are symmetrical with one another and the corresponding values are therefore reciprocal with each other. When the factor on the vertical axis is more important than the factor on the horizontal axis this value varies between 1 and 9 . Contrary to the above the value varies between the reciprocals $1 / 2$ and $1 / 9$.

Table 1 - Nine-point scale of preference between two parameters in AHP (Saaty 1980)

\begin{tabular}{ll}
\hline Scales & Degree of preferences \\
\hline 1 & Equal importance \\
3 & Moderate prevalence of one over another \\
5 & Strong or essential prevalence \\
7 & Very strong or demonstrated prevalence \\
9 & Extremely high prevalence \\
$2,4,6,8$ & Intermediate values \\
Reciprocals & For inverse comparison \\
\hline
\end{tabular}

A basic requirement of weighting in AHP is that the sum of all weights equals 1 as the weighted linear combination calculation requires. After the pairwise score rating the consistency used to build the matrix is checked by the consistency ratio (CR), which depends on the number of parameters and is automatically calculated by the software. The CR is indicative of the probability that the matrix ratings were randomly generated. Saaty (1980) prescribes that the CR must be less than 0.1 to accept the computed weights otherworld the ratings should be re-evaluated. In Table 2 the $\mathrm{CR}$ is 0.07 indicating the adequate degree of consistency of the comparison matrix.

Table 2 - Matrix of factor weight evaluation

\begin{tabular}{lccccccccccc}
\hline & (a) & (b) & (c) & (d) & (e) & (f) & (g) & (h) & (i) & (j) & Weights \\
\hline Lithology (a) & 1 & 2 & 3 & 4 & 5 & 5 & 5 & 5 & 5 & 6 & 0.269 \\
Slope gradient (b) & $1 / 2$ & 1 & 3 & 3 & 4 & 3 & 5 & 5 & 5 & 5 & 0.209 \\
Proximity to thrusts (c) & $1 / 3$ & $1 / 3$ & 1 & 3 & 3 & 3 & 3 & 3 & 3 & 5 & 0.137 \\
Land use (d) & $1 / 4$ & $1 / 3$ & $1 / 3$ & 1 & 3 & 3 & 3 & 3 & 3 & 5 & 0.107 \\
Soil thickness (e) & $1 / 5$ & $1 / 4$ & $1 / 3$ & $1 / 3$ & 1 & 2 & 2 & 2 & 3 & 5 & 0.070 \\
Curvature (f) & $1 / 5$ & $1 / 3$ & $1 / 3$ & $1 / 3$ & $1 / 2$ & 1 & 2 & 2 & 2 & 2 & 0.055 \\
Distance from & $1 / 5$ & $1 / 5$ & $1 / 3$ & $1 / 3$ & $1 / 2$ & $1 / 2$ & 1 & 1 & 3 & 5 & 0.050 \\
streams(g) & & & & & & & & & & & \\
Distance from roads (h) & $1 / 5$ & $1 / 5$ & $1 / 3$ & $1 / 3$ & $1 / 2$ & $1 / 2$ & 1 & 1 & 3 & 5 & 0.050 \\
Rainfalls (i) & $1 / 5$ & $1 / 5$ & $1 / 3$ & $1 / 3$ & $1 / 3$ & $1 / 2$ & $1 / 3$ & $1 / 3$ & 1 & 3 & 0.033 \\
Aspect (j) & $1 / 6$ & $1 / 5$ & $1 / 5$ & $1 / 5$ & $1 / 5$ & $1 / 2$ & $1 / 5$ & $1 / 5$ & $1 / 3$ & 1 & 0.021 \\
& & & & & & & & & & & CR=0.07 \\
\hline
\end{tabular}

After the development of the weights, all factors were combined using the Weighted Linear Combination (WLC) method which is one of the best known and most commonly used multicriteriaGIS based methods (Malczewski 2000, Ayalew et al. 2004). In the procedure for multi-criteria analysis using WLC it is necessary not only for the weights of the factors to have a sum of 1 but also that the classes of the factors are standardized to a common numeric range. The rating of the 
classes within a factor shown in Table 3 was based on the relative importance of each class obtained from field knowledge according to the obvious relationship between each conditioning factor and the distribution of the landslides in the broader area.

In our case in order to approve a standardized measurement system across all factors we must standardized them to a uniform susceptibility rating scale. This was achieved using the formula in Equation 1 by dividing each rank value by the maximum value for the specific given factor and afterwards multiply it by 100 in order to achieve integer numbers and get values between 0 and 100. In this way the ranked values of the classes were standardized according to the relative distance between the original and the maximum rank value and the maximum rank value for the classes of each factor is always equal to 100 . The produced integer numbers ranking from 0 to 100 were assigned as relative values for each class of all the factors as shown in Table 3 .

\section{Equation 1 - Formula for rank values standardization}

$$
\mathrm{X}_{i j}^{\prime}=\mathrm{X}_{i j} / \mathrm{X}_{\mathrm{j}}^{\mathrm{max} *} \text { standardized range. }
$$

where $\mathrm{X}_{i j}^{\prime}$ is the standardized rank value for the $i_{\mathrm{th}}$ class for the $j_{\mathrm{th}}$ factor, $\mathrm{X}_{i j}$ is the primary rank value, $X_{\mathrm{j}}^{\max }$ is the maximum rank value for the $j_{\text {th }}$ factor and standardized range $=100$.

Table 3 - The weights and rank values given to each factor and their classes respectively

\begin{tabular}{|c|c|c|c|c|}
\hline Factors & weights & Classes & $\begin{array}{l}\text { Rank } \\
\text { values }\end{array}$ & $\begin{array}{l}\text { Standardized } \\
\text { ratings }\end{array}$ \\
\hline \multirow[t]{8}{*}{ Lithology } & 0.2690 & Alluvial \& scree & 7 & 100 \\
\hline & & Schists \& Phyllites & 6 & 85 \\
\hline & & Flysch formations & 5 & 71 \\
\hline & & Fine-grained post-alpine fm & 4 & 57 \\
\hline & & $\begin{array}{l}\text { Intermediate post-alpine fa- } \\
\text { cies }\end{array}$ & 3 & 43 \\
\hline & & $\begin{array}{l}\text { Coarse-grained post-alpine } \\
\text { fm. }\end{array}$ & 2 & 28 \\
\hline & & Thin-bedded carbonates & 1 & 14 \\
\hline & & Massive carbonates & 0 & 0 \\
\hline \multirow[t]{8}{*}{ Land use } & 0.107 & Shrubs \& grassland & 7 & 100 \\
\hline & & $\begin{array}{l}\text { Transitional forest-shrub ar- } \\
\text { eas }\end{array}$ & 6 & 85 \\
\hline & & Mixed cultivated-shrub areas & 5 & 71 \\
\hline & & Forests & 4 & 57 \\
\hline & & Cultivated areas & 3 & 43 \\
\hline & & Rocky areas & 2 & 28 \\
\hline & & Built-up areas & 1 & 14 \\
\hline & & Arable land & 0 & 0 \\
\hline \multirow[t]{4}{*}{ Slope gradient } & 0.209 & Steep slopes, $30^{0}-45^{0}$ & 5 & 100 \\
\hline & & $\begin{array}{l}\text { Moderately steep slopes, } 15^{0} \text { - } \\
30^{\circ}\end{array}$ & 4 & 80 \\
\hline & & Escarpments, $>45^{\circ}$ & 3 & 60 \\
\hline & & Gentle slopes, $5^{0}-15^{0}$ & 2 & 40 \\
\hline
\end{tabular}




\begin{tabular}{|c|c|c|c|c|}
\hline Factors & weights & Classes & $\begin{array}{c}\text { Rank } \\
\text { values }\end{array}$ & $\begin{array}{l}\text { Standardized } \\
\text { ratings }\end{array}$ \\
\hline & & Very gentle slopes, $<5^{0}$ & 1 & 20 \\
\hline \multirow[t]{5}{*}{ Curvature } & $0 ., 055$ & $<-1.5$ & 4 & 100 \\
\hline & & $-1.5--0.5$ & 3 & 75 \\
\hline & & $-0.5-0$ & 2 & 50 \\
\hline & & $>0$ & 1 & 25 \\
\hline & & $=0$ & 0 & 0 \\
\hline \multirow[t]{2}{*}{ Aspect } & 0.021 & N \& NW facing slopes & 1 & 100 \\
\hline & & all other directions & 0 & 0 \\
\hline \multirow[t]{5}{*}{ Soil thickness } & 0.070 & Deep soil & 4 & 100 \\
\hline & & $\begin{array}{c}\text { Mixed shallow \& deep soil } \\
\text { areas }\end{array}$ & 3 & 75 \\
\hline & & Mixed bare rock \& deep soil & 2 & 50 \\
\hline & & Shallow soil & 1 & 25 \\
\hline & & Bare rock & 0 & 0 \\
\hline \multirow[t]{3}{*}{ Rainfalls } & 0.033 & $>1500 \mathrm{~mm}$ & 3 & 100 \\
\hline & & $1000-1500 \mathrm{~m}$ & 2 & 67 \\
\hline & & $<1000 \mathrm{~mm}$ & 1 & 33 \\
\hline \multirow{3}{*}{$\begin{array}{l}\text { Proximity to } \\
\text { thrusts/faults }\end{array}$} & 0.137 & $<150 \mathrm{~m}$ & 2 & 100 \\
\hline & & $150-300 \mathrm{~m}$ & 1 & 50 \\
\hline & & $>300 \mathrm{~m}$ & 0 & 0 \\
\hline \multirow[t]{2}{*}{ Distance from roads } & 0.050 & $<50 \mathrm{~m}$ & 1 & 100 \\
\hline & & $>50 \mathrm{~m}$ & 0 & 0 \\
\hline \multirow[t]{2}{*}{ Distance from streams } & 0.050 & $<50 \mathrm{~m}$ & 1 & 100 \\
\hline & & $>50 \mathrm{~m}$ & 0 & 0 \\
\hline
\end{tabular}

By applying the WLC method, the weight value assigned for each factor was multiplied by the standardized rank values given to the classes and numerically added according to Equation 2 in order to produce a Landslide Susceptibility Index (LSI) map.

\section{Equation 2 - Evaluation of LSI}

\section{$\mathrm{LSI}=\Sigma \mathrm{Fw} * \mathrm{Fr}$}

where $\mathrm{Fw}=$ weight of each factor and $\mathrm{Fr}=$ rating of each factor class.

As a result the LSI value for each pixel of the output susceptibility map was calculated according to equation 3 :

\section{Equation 3 - Evaluation of pixels values in the susceptibility map}

$$
\mathrm{M} i=\Sigma_{j} \mathrm{w}_{j} \mathrm{x}_{i j}
$$

where $\mathrm{M} i=$ pixel, $\mathrm{x}_{i j}=$ standardized rank value of the $i_{\mathrm{th}}$ class in the $j_{\mathrm{th}}$ factor and $\mathrm{w}_{j}=$ weight of the $j_{\text {th }}$ factor. 


\section{The susceptibility map}

As a result of the adopted weighting-ranking system the landslide susceptibility index (LSI) values in the resulting susceptibility map are varying within the range of 0 and 100 . Reclassification of the original susceptibility map was needed, as it contained many micro-facets, which make its interpretation difficult. The final map showing the spatial distribution of the LSI was classified into five categories namely, "very low", "low", "moderate", "high" and "very high" as shown in Fig. 3. This classification, which divides the study area into five susceptibility zones was based on natural breaks in the cumulative frequency histogram of LSI values. The higher the LSI is, the more susceptible the area is to landsliding. The "very low" category has a ratio below 31 , the "low" is from 31 to 42 , the "moderate" is from 42 to 51 , the "high" is from 51 to 63 and the "very high" is above 63. Surfaces classified as being of "high" and "very high" susceptibility constitute $21,7 \%$ of the study area, surfaces of "very low" and "low" susceptibility account for 23,8 and $39,7 \%$ respectively and surfaces of "moderate" susceptibility covers $14,8 \%$ of the total area.

The susceptibility map shows that the high susceptible zones were located mainly in areas where flysch and mica-schist formations outcrop on steep slopes near major fault zones and thrust surfaces. Thus, those areas have a combination of factors that lead to a relative high landslide potential. In order to examine the potential landslide risk in respect to villages, the settlements of the study area were overlaid on the susceptibility map. This correlation suggests that 18 settlements are located within high and very high landslide potential zones.

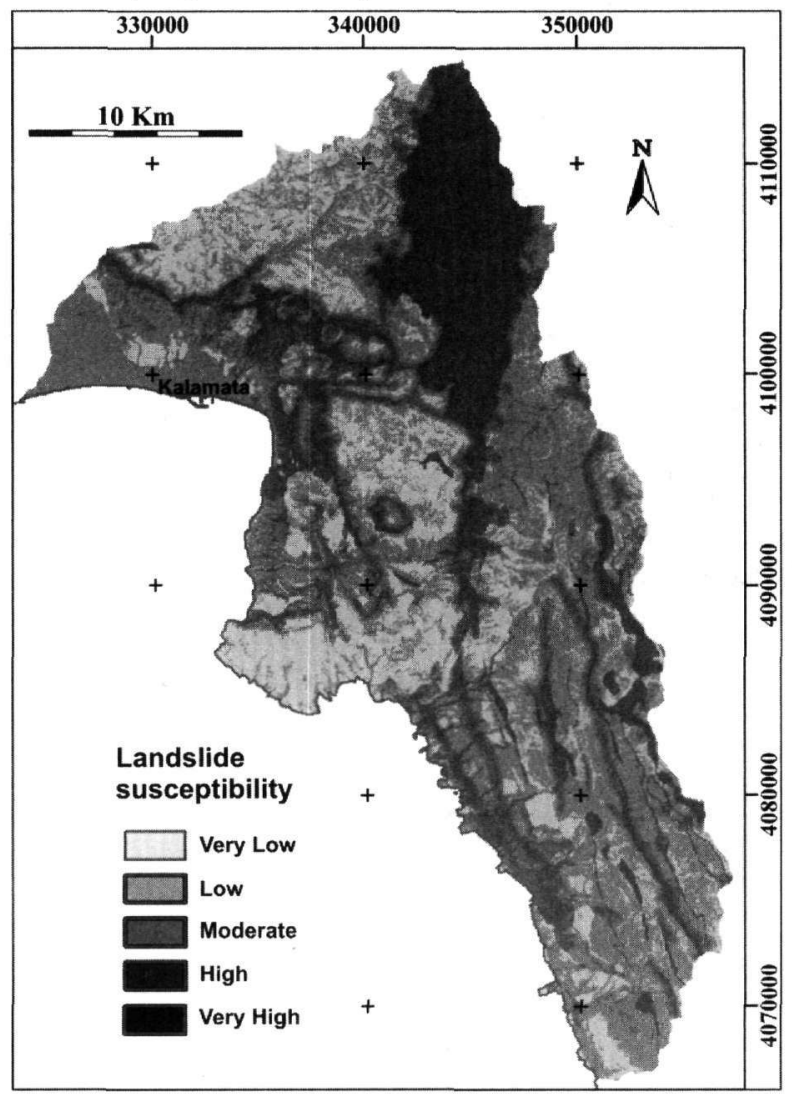

Figure 3 - Reclassified landslide susceptibility map of the study area 


\section{Conclusions}

For analyzing landslide susceptibility in the study area ten thematic maps were created one for each landslide-controlling factor. Applying AHP method the weight values of the factors were obtained and by implementing WLC method the landslide susceptibility index (LSI) was calculated for every cell. The final stage was the production of the reclassified landslide susceptibility map showing five landslide susceptible zones as illustrated in Fig.3.

In order to test the performance of the produced susceptibility map we compare it with the distribution of the major landslide events occurred in the study area and the predicted map showed satisfactory results. The occurrence of landslides in the moderate or low susceptibility zones is attributed to local effects i.e. the orientation of the local discontinuities surfaces which couldn't be incorporated in our analysis due to the extensive study area and the map scale used (1:50/000).

The landslide-prone areas, delineated by the susceptibility map, represent an important basis for the assessment of landslide hazard over the study area. Thus, the produced susceptibility map can be very useful to decision-makers for choosing suitable locations for future planning in large-scale regions. For example landslide prone areas that have not yet been developed can be restricted to compatible land uses. Additionally planers and developers could use the susceptibility map to identify roads and settlements subject to damage by future landslides and take drastic measures for preventing the landslide events. Moreover it can be used as planning guide of new roads constructions steering the decision makers away from areas prone to landslides or indicating that special design considerations have to be applied in road constructions through hazardous areas.

\section{References}

Akgun, A., and Bulut, F., 2007. GIS-based landslide susceptibility for Arsin-Yomra (Trabzon, North Turkey) region, Environ. Geol., 51(8), 1377-1387.

Aleotti, P., and Chowdhury, R., 1999. Landslide hazard assessment: summary review and new perspectives, Bull. Eng. Geol. Environ., 58, 21-44.

Ayalew, L., Yamagishi, H., and Ugana, N., 2004. Landslide susceptibility mapping using GISbased weighted linear combination, the case in Tsugawa area of Agano River, Niigata Prefecture, Japan, Landslides, 1, 73-81.

Ayalew, L., YAmagishi, H., Marui, H., and Kanno, T., 2005. Landslides in Sado Island of Japan: Part II. GIS-based susceptibility mapping with comparisons of results from two methods and verifications, Engineering Geology, 81, 432-445.

Barredo, J.I., Benavides, A., Hervas, J., and Van Westen, C.J., 2000. Comparing heuristic landslide hazard assessment techniques using GIS in the Trijana basin, Gran Canaria Island, Spain, Int. J. Appl. Earth Obser. Geoinf., 2, 9-23.

Carrarra, A., Cardinali, M., Detti, R., Guzzeti, F., Pasqui, V., and Reichenbach, P., 1991. GIS techniques and statistical models in evaluating landslide hazard, Eearth Surface Processes and landforms, 16(5), 427-445.

Carrarra, A., Cardinali, M., Guzzeti, F., and Reichenbach, P., 1995. GIS-based techniques for mapping landslide hazard. In A. Carara and F. Guzzetti (eds), Geographical information systems in assessing natural hazards, Kluwer, Dordrecht, 135-176.

Fountoulis, I., Ladas, I., Spyridonos, E., and Mariolakos, I., 2004. The role of the tectonics and hydrology for the Tsakona landslide (SW Peloponnese, Greece), Bull. Geol. Soc. Greece, XXXVI/4, 1872-1881. (in Greek with English abstract)

Guzzeti, F., Carrarra, A., Cardinali, M., and Reichenbach, P., 1999. Landslide hazard evaluation: a review of current techniques and their application in a multiscale study, Central Italy, Geomorphology, 31, 181-216. 
Huabin, W., Gangjun, L., Weiya, X., and Gonghui, W., 2005. GIS-based landslide hazard assessment: an overview. Progress in Physical Geography, 29(4), 548-567.

IGME publications, Geological map of Greece, scale 1:50.000, (Kalamata, Kardamili, Xirokambion, Sparti and Areopolis sheets).

Malczewski, J., 2000. On the use of Weighted Linear Combination Method in GIS: common and best practice approaches, Transactions in GIS, 4(1), 5-22.

Malczewski, J., 2006. GIS-based multicriteria decision analysis: a survey of the literature, International Journal of Geographical Information Science, 20(7), 703-726.

Mariolakos, I., Schneider, A., Fountoulis, I., and Vouloumanos, N., 1993. Paleogeography, sedimentation and neotectonic implications at the Kambos depression and Kitries bay area, Bull. Geol. Soc. Greece, XXVIII/1, 397-413.

Mariolakos, I., Lozios, S., and Logos, E., 1995. The neotectonic macrostructure of southern Peloponnesus, The earthquakes of September 13, 1986. Seminar on active faults, XV Congress of the Carpatho-Balcan Geological Association, 51-60, Athens.

Ministry of Agriculture, Forest Service publications. Soil map of Greece. Land resource maps, scale 1:50.000, (Areopolis, Sparti, Kalamata, Kardhamili and Xirokambion sheets).

Saaty, T.L., 1980. The Analytical Hierarchy Process, McGraw Hill, New York, 350pp. 